SBORNÍK NÁRODNIIHO MUZEA V PRAZE

Řada B - Př́rodní vědy•sv. 70 • 2014 • čís. 3-4 • s. 125-128
ACTA MUSEI NATIONALIS PRAGAE

Series B - Historia Naturalis • vol. 70 • 2014 • no. 3-4 • pp. 125-128

\title{
RUDOLF JAN PROKOP, OCTOGENARIAN
}

\section{VOJTĚCH TUREK}

National Museum, Department of Palaeontology, Václavské náměstí 68, 11579 Praha 1, Czech Republic; e-mail: vojtech_turek@nm.cz
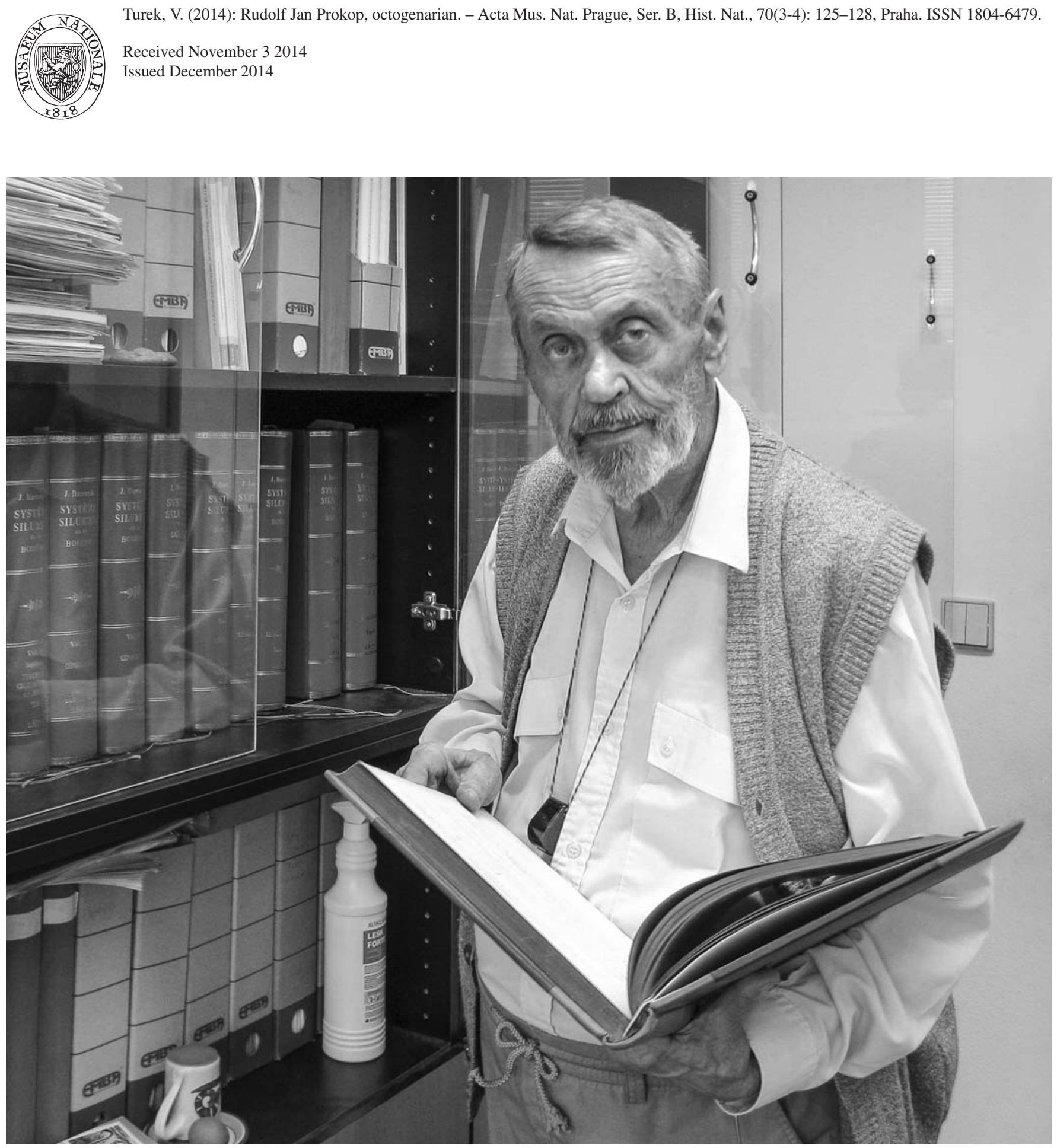

Text-fig. 1. Dr. Rudolf J. Prokop. Photo V. Turek 2014. 
On July $25^{\text {th }}, 2014$, the noted palaeontologist Rudolf J. Prokop celebrated his $80^{\text {th }}$ birthday in the company of his colleagues. He started his scientific career in 1960 as a geologist for the Central Geological Survey in Prague, where he worked until 1969. That year, he transferred to the National Museum, Prague as a paleontologist and curator of the Early Palaeozoic collection. He focused his scientific interest on echinoderms, particularly crinoids, although he did not neglect other echinoderms, such as eocrinoids, carpoids, ophiuroids, asterozoids and holothurians. He also studied other invertebrates, like trilobites and polyplacophorans, and worked on biostratigraphy and palaeoecology. He spent a great deal of time making palaeontology accessible to the public, via scenography in exhibitions, popular-scientific publications and books. His retirement in 1996 was essentially a formality, since he continued his work with little change. Václav Petr wrote Dr. Prokop's biography on the occasion of his previous birthdays (1994a, 1994b, 1999, 2004, 2004). His complete biography is also listed in cited publications up to 2004. For the occasion of his $80^{\text {th }}$ birthday, that is supplemented by the material given here, i.e., additional publications from the latter part of 2004, and all of 2005-2014.

Despite his advanced age and declining health, Dr. Prokop continues to work, both in hard science and as a popularizer, in close personal cooperation with the Department of Palaeontology of the National Museum. He assists with taxonomic determination and proper safe storage of echinoderm collection material in the new depositories of the National Museum in Prague-Horní Počernice, assists with evaluating material from preservative field work in Koněprusy limestone conducted jointly by the National Museum and the Čertový Schody (Devil's Stairs) Quarry. The results of this research are a fundamental expansion of our understanding of echinoderm diversity in the Lower Devonian Koněprusy area. In the last ten years he has published 16 scientific papers on Devonian crinoids and two on other groups of echinoderms of the Barrandien area. Besides several new taxa at the genus and species level, he described an entire family of camerate crinoids, Aishacrinidae. He also belongs among regular contributors to the Bulletin of the Czech Geological Society, and has privately published accounts of his travels to foreign countries. And so in the years still to come, we wish Dr. Prokop continued health, and continued enthusiasm for his scientific endeavors, that he may continue to enrich our fund of knowledge regarding echinoderms of the Late Palaeozoic of Bohemia, as well as participating in social gatherings with his colleagues in the Department of Palaeontology of the National Museum, and the palaeontological community at large.

\section{Rudolf Jan Prokop osmdesátníkem}

25. července 2014 oslavil ve společnosti svých kolegů 80. narozeniny významný český paleontolog RNDr. Rudolf J. Prokop, CSc. Svou vědeckou kariéru začal v roce 1960 jako geolog v Ústředním ústavu geologickém v Praze, kde působil do roku 1969. V témže roce nastoupil na místo paleontologa a kurátora sbírek staršího paleozoika v Národním muzeu v Praze. Svou vědeckou činnost pak zaměřil na ostnokožce, a to zejména na lilijice, i když se intenzívně zajímal i o další skupiny ostnokožců (např. eokrinoidy, karpoidy, hadice, hvězdice, sumýše). Studoval však i některé jiné bezobratlé, např. trilobity a chroustnatky, věnoval se otázkám biostratigrafickým a paleoekologickým. Mnoho času věnoval také popularizaci paleontologie prostřednictvím scénářru výstav i populárně-vědeckých publikací, a to nejen článků, ale i knih. Jeho odchod do důchodu v roce 1996 byl víceméně formální, nebot' svou pracovní aktivitu nikterak neomezil. Jeho životopis k předchozím životním jubileím podrobně zpracoval Václav Petr (1994a, 1994b, 1999, 2004). V citovaných publikacích je také uvedena kompletní bibliografie R. J. Prokopa do r. 2004. Při př́ležitosti dovršených osmdesáti let je zde připojen dodatek publikací vyšlých v letech 2004-2014.

Přes pokročilý věk i zhoršený zdravotní stav je R. J. Prokop stále vědecky i popularizačně velmi aktivní, v úzkém vědeckém i osobním kontaktu s paleontologickým oddělením Národního muzea. Podílí se na taxonomické determinaci a definitivním ukládání sbírkových fondů ostnokožců v nových depozitářích Přírodovědeckého muzea v PrazeHorních Počernicích, spolupracuje na vyhodnocování materiálu ze záchranných výzkumů koněpruských vápenců realizovaných $\mathrm{v}$ rámci smlouvy mezi Národním muzeem a Velkolomem Čertovy schody. Výsledkem tohoto výzkumu je zcela zásadní rozšíření obrazu o diverzitě společenstev ostnokožců žijících na spodnodevonském koněpruském útesu a jeho periferii. V posledních deseti letech publikoval šestnáct vědeckých článků, vesměs zaměřených na devonské ostnokožce barrandienu. Kromě několika nových taxonů na úrovni rodu a druhu popsal také novou čeled' kamerátních krinoidů Aishacrinidae. Patři také k pravidelným přispěvovatelům do Zpravodaje České geologické společnosti, soukromým tiskem mu vyšly i krátké př́běhy z jeho zahraničních cest. A tak i do dalších let přejeme R. J. Prokopovi dostatečně pevné zdraví a neutuchající pracovní elán, aby mohl nejen nadále přispívat $\mathrm{k}$ rozširrování znalostí o ostnokokožcích českého staršího paleozoika, ale plně se účastnit se společenského dění s kolegy z paleontologického oddělení Národního muzea i celé paleontologické obce.

\section{References}

Petr, V. (1994a): Z čeho vlastně jsou vápence Českého krasu? Aneb RNDr. Rudolf Prokop, CSc. šedesátníkem. - Český kras, 19: 55-62.

Petr, V. (1994b): $60^{\text {th }}$ Birthday of Rudolf Prokop's. - Časopis Národního muzea, Řada př́rodovědná, 163(1-4): 121-128.

Petr, V. (1999): $65^{\text {th }}$ Birthday of dr. Rudolf J. Prokop. Časopis Národního muzea, Řada př́rodovědná (Journal of the National Museum, Natural History Series): 168(1-4): 5-6.

Petr, V. (2004): Dr. Rudolf Jan Prokop $-70^{\text {th }}$ birthday (Rudolf before his employment at the National Museum, Praha). - Časopis Národního muzea, Řada př́rodovědná (Journal of the National Museum, Natural History Series), 173(1-4): 6-10. 


\section{Supplement to the bibliography of Rudolf J. Prokop (latter part of 2004, all of 2005-2014)}

Prokop, R. J. (2004): Lampterocrinus astroferus sp. n. (Crinoidea, Camerata) from the Upper Silurian (Ludlow) of the Barrandian area (Czech Republic). - Journal of the Czech Geological Society, 49(3-4): 137-140.

Parsley, R. L., Prokop R. J. (2004): Functional morphology and paleoecology of some sessile Middle Cambrian echinodems from the Barrandian region of Bohemia. Bulletin of Geosciences, 79(3): 147-156.

Mergl, M., Prokop, R. J. (2006): Lower Ordovician cystoids (Rhombifera, Diploporita) from the Prague Basin (Czech Republic). - Bulletin of Geosciences, 81(1): 1-15.

Koverdynský, B. - Prokop, R. J. (2006): Crinoid skeletal ossicles in the Šléglov Formation at the Velké Vrbno Dome (Moravia, Czech Republic) and their stratigraphic significance. - Journal of the National Museum, Natural History Series, 175(3-4): 91-96.

Hotchkiss, F. H. C., Prokop, R. J., Petr, V. (2007): Isolated ossicless of the family Eospondylidae Spencer et Wright, 1966 in the Lower Devonian of Bohemia (Czech Republic) and corrections of the systematic position of eospondylid brittlestars (Echinodermata: Ophiuroidea: Oegophiuroida). - Acta Musei Nationalis Pragae, Series B - Historia Naturalis, 63(1): 3-18.

Turek, V., Horný, R., Prokop, R. (2007): Verdwenen in het hart van Europe zeeën. -Wetenschappelijke Bibliotheek van Natuurwetenschap \& Technik 92, 240 pp Amsterdam. (Holandské vydání knihy “Ztracená moře uprostřed Evropy").

Prokop, R. J. (2007): Kosterní zbytky ježovek v silurských a devonských vápencích Českého krasu. - Echinoid skeletal remains in the Silurian and Devonian limestones of the Czech Karst, Barrandian area (Czech Republic). Český kras, 33: 16-21.

Prokop, R. J. (2008): Povídky z cest (Jak jsem kupoval sikhský nůž). - Zpravodaj České geologické společnosti, 6 ( leden 2008): 29-30.

Prokop, R. J. (2008): Max a poklička. - Zpravodaj České geologické společnosti, 7 (červenec 2008): 37-38.

Prokop, R. J. (2009): Eucalyptocrinites veles sp. n. (Crinoidea, Camerata) from the Silurian of Bohemia (Czech Republic). - Journal of the National Museum (Prague), Natural History Series, 177(3): 33-36.

Prokop, R. J., Slámová, R. (2009): New crinoids (col.) from the Zlíchovian Limestone (Lower Devonian, lower Emsian) of the Barrandian area (Czech Republic). Journal of the National Museum (Prague), Natural History Series, 177(4): 37-47.

Prokop, R. J. (2009): Jak jsem se bál ve Slovenském krasu. - Zpravodaj České geologické společnosti, 8 (leden 2009): 39-40.

Prokop, R. J. (2009): Holamptocrinus argutus gen. et sp. n. (Crinoidea, col.) from Lower Devonian, (Dalejan) of the Barrandian area (Czech Republic). - Journal of the National Museum (Prague), Natural History Series, 177(5): 49-51.

Prokop, R. J. (2009): Ammonicrinus bulbosus sp. n. (col.), (Crinoidea, Flexibilia) from the Lower Devonian
Koněprusy Limestone, Barrandian area (Czech Republic). - Journal of the National Museum (Prague), Natural History Series, 177(12): 161-64.

Prokop, R. J. (2009): Krokodýli a chobotnice. - Zpravodaj České geologické společnosti, 9 (červenec 2009): 26-27.

Prokop, R. J. (2010): Jak jsem na salinách u Madrásu kupoval sůl. - Zpravodaj České geologické společnosti, 11 (červenec 2010): 37-38.

Prokop, R. J. (2010): Aishacrinidae, a new family of camerate crinoids from the Silurian of Bohemia Czech Republic Journal of the National Museum (Prague), Natural History Series, 179(5): 41-46.

Prokop, R. J., Petr, V. (2010): New finds of Vadarocrinus vassa Prokop, 1984 (Crinoidea, Petalocrinidae) in the Koněprusy and Loděnice Limestones (Lower Devonian, Pragian) of the Barrandian area, Czech Republic. - Journal of the National Museum (Prague), Natural History Series, 179(14): 147-152.

Prokop, R. J. (2010): Těžko uvěřitelné avšak pravdivé povídky. - Soukromý tisk. Praha. 174 pp.

Prokop, R. J. (2011): Zářící oči ve tmě. - Zpravodaj České geologické společnosti, 12 (leden 2011): 32-34.

Prokop, R. J. (2011): Burina. - Zpravodaj České geologické společnosti, 13 (červenec 2011): 31-34.

Prokop, R. J. (2011): Těžko uvěřitelné avšak pravdivé povídky. - 2. doplněné vydání, soukromý tisk. Praha. $57 \mathrm{pp}$.

Prokop, R. J. (2011): Carpocrinus chlupaci sp. n. and Bouskacrinus solus gen. et sp. n. (Echinodermata, Crinoidea) from the Koněprusy Limestone (Lower Devonian, Pragian) of the Barrandian area, Czech Republic. - Journal of the National Museum (Prague), Natural History Series, 180(9): 127-31.

Prokop, R. J. (2012): Trapas v Liverpoolu. - Zpravodaj České geologické společnosti, 14 (leden 2012): 31-32.

Prokop, R. J. (2012): A new species of the genus Follicrinus (Echinodermata, Crinoidea) from the Middle Devonian (Eifelian) of the Czech Republic. - Journal of the National Museum (Prague), Natural History Series, 181(1): 1-3.

Prokop, R. J., Turek, V. (2012): Výzkum ostnokožců z nové lokality "bílých vrstev" v koněpruských vápencích ve Velkolomu Čertovy schody-západ (spodní devon, prag). Investigation of echinoderms from the new locality so-called "white beds" in the Koněprusy Limestone in the Velkolom Čertovy schody-West quarry (Lower Devonian, Pragian). - Zprávy o geologických výzkumech v roce 2011 / C - Paleontologie: 144-145.

Prokop, R.J. (2012): Expedice Maghreb (= Diplomatem v Africe). - Zpravodaj České geologické společnosti, 15 (červenec 2012): 40. Praha.

Prokop, R. J., Slámová, R. (2012): New species of crinoids based on their columnals and stem fragments (col.) from the Lower Devonian Zlíchov Limestone (Barrandian area, the Czech Republic). - Acta Musei Nationalis Pragae Series B - Historia Naturalis, 68(3-4): 133-138.

Prokop, R.J. (2013): Poprvé u moře. - Zpravodaj České geologické společnosti 16 (leden 2013): 31-33.

Prokop, R. J. (2013): Těžko uvěřitelné avšak pravdivé povídky. - 3. upravené a doplněné vydání, soukromý tisk. Praha. 94 pp. 
Prokop, R. J. (2013): Průvodcem v Egyptě. - Zpravodaj České geologické společnosti, 17 (červenec 2013): 49-50.

Prokop, R. J. (2013): Simakocrinus gen. nov. (Crinoidea, col.) from the Bohemian Early and Middle Devonian of the Barrandian Area (The Czech Republic). - Acta Musei Nationalis Pragae, Series B - Historia Naturalis, 69(1-2): 65-68.

Prokop, R. J. (2014): Černá kočka z Dubrovníka. - Zpravodaj České geologické společnosti, 18 (leden 2014): 43-45.
Prokop, R. J. (2014): Jak jsme s přítelem Václavem unikli v Kalkatě obarvení. - Zpravodaj České geologické společnosti, 19 (červenec 2014): 34-36.

Prokop, R. J., Turek, V. (2014): Thecal cup of the crinoid Edriocrinus preserved inside the shell of an orthocone cephalopod: Middle Devonian, (Eifelian) from Bohemia. - Acta Musei Nationalis Pragae Series B - Historia Naturalis, 68(3-4): 219-222. 